\title{
When Racial Inequalities Return: Assessing the Restratification of Cuban Society 60 Years After Revolution
}

\author{
Katrin Hansing \\ Bert Hoffmann
}

\begin{abstract}
Few political transformations have attacked social inequalities more thoroughly than the 1959 Cuban Revolution. As the survey data in this article show, however, sixty years on, structural inequalities are returning that echo the prerevolutionary socioethnic hierarchies. While official Cuban statistics are mute about social differences along racial lines, the authors were able to conduct a unique, nationwide survey with more than one thousand respondents that shows the contrary. Amid depressed wages in the state-run economy, access to hard currency has become key. However, racialized migration patterns of the past make for highly unequal access to family remittances, and the gradual opening of private business disfavors AfroCubans, due to their lack of access to prerevolutionary property and startup capital. Despite the political continuity of Communist Party rule, a restructuring of Cuban society with a profound racial bias is turning back one of the proudest achievements of the revolution.
\end{abstract}

Keywords: Cuba, social inequality, race, socialism, migration, remittances

$\mathrm{T}_{\mathrm{t}}^{\mathrm{h}}$ he 1959 Cuban Revolution radically broke with a past in which "class" tended to influence and overlap most aspects of social life, including "race," gender, income, education, and territory. The "centralized, state-sponsored economy, which provided full employment and guaranteed modest income differences, was the great social elevator of the lower strata of society. As a result, by the 1980s Cuba had become one of the most egalitarian societies in the world" (Mesa-Lago and PérezLópez 2005, 71).

Katrin Hansing is an associate professor of sociology and anthropology at Baruch College, City University of New York. katrinhansing@gmail.com. ORCID 0000-0003-2769-1158. Bert Hoffmann is a senior research fellow at GIGA, the German Institute of Global and Area Studies, and a professor of political science at Freie Universität Berlin. bert.hoffmann@gigahamburg.de. ORCID 0000-0001-7522-3610. Conflicts of interest: Katrin Hansing and Bert Hoffmann declare none.

(C) 2020 University of Miami.

This is an Open Access article, distributed under the terms of the Creative Commons Attribution license (http://creativecommons.org/licenses/by/4.0/), which permits unrestricted reuse, distribution, and reproduction in any medium, provided the original work is properly cited.

DOI 10.1017/lap.2019.59 
Sixty years after the triumph of the revolution, Communist Party rule persists. However, beneath this veneer of political continuity, socialist Cuba is undergoing a profound restructuring of its society. Social inequalities have become visible in everyday life. The political leadership is reluctant to address this issue, as it touches on a core aspect of its revolutionary legitimacy. As a result, Cuba's National Office of Statistics (ONE) publishes little data on the widening socioeconomic gap.

This article provides new and substantial data on the restratification of Cuban society that is currently taking place. The authors were able to conduct a unique survey with 1,049 Cubans across the island, which clearly shows the growing patterns of socioeconomic disparity. More disturbingly, it also reveals how strongly racialized this new social structure is.

The historical backdrop for the return of social inequalities is the demise of the Soviet Union, Cuba's longtime ally and benefactor. In the 1990s, the island fell into a profound economic crisis (CEPAL 1997; Mesa-Lago 2005). The state economy's capacity to provide basic goods and services, as well as incomes, sharply declined (Brundenius and Torres Pérez 2013; Domínguez et al. 2012), and the value of the Cuban peso (CUP) fell dramatically. In 1993 the government opened the country to a dual monetary system by allowing a hard currency to circulate-initially the U.S. dollar, which, over time, was replaced by the convertible peso, or CUC, which is pegged to the U.S. dollar (Ritter 1995; Ritter and Rowe 2002).

After the crisis hit rock bottom in 1993-94, the economy regained some stability, but with an exchange rate of 26:1, the dual currency situation continues to sharply divide both the economy and society to this day (Eckstein 2004; Vidal and Everleny 2013). This is most visible in the devaluation of state salaries. In 2018, the average monthly salary was CUP 767 (ONE 2018), which translates into a mere US\$30. ${ }^{1}$

It is in this context that alternative sources of income, other than state salaries, have acquired extraordinary significance. Two such sources stand out: money transfers from abroad, generally referred to as remittances; and private market activities, whether informal or as legalized self-employment or small-scale businesses. However, the potential to tap into these resources is far from equally distributed in Cuban society. As a result, new social inequalities are emerging and doing so along clearly visible racial lines.

The growing inequalities in Cuba have been addressed by numerous scholars on and off the island (Bastian 2018; de la Fuente 2011; Espina Prieto 2010; Espina Prieto and Togores 2012; Hansing and Optenhögel 2015; Hansing 2017). While these studies provide important insights, most provide anecdotal evidence or are based on interviews, in-depth ethnographies, or biographical studies with limited scope. What they all struggle with is a lack of comprehensive data. Sarah Blue's important contribution (2007) has so far provided the only survey data on the issue. However, it is limited to a sample of 334 families in the city of Havana and was undertaken in December 2000; that is, almost two decades ago, when remittances, and particularly investment in private business, were still on much lower levels, international travel was heavily restricted, and the Internet was inaccessible to most of the population. ${ }^{2}$ 
As for official statistics, the Cuban census regularly collects a wide array of data. However, Cuba's ONE publishes these data selectively, and some significant data not at all. Regarding income inequality, for instance, ONE publishes data only for salaries in Cuban pesos (CUP), not for the much more important hard currency incomes (CUC). Also, the Gini coefficient, the international standard measure for income inequalities, has been calculated only on a CUP basis. As such, it is all but meaningless, given the country's dual currency context. This practice has now been discontinued, as no Gini score has been published since 2000 (Monreal 2018). ${ }^{3}$

Another key deficit in Cuba's official statistics relates to the socioethnic composition of the population. The national census does ask about "skin color" (color de piel), using three categories: white, black, and mulatto. For a long time, however, data correlating "skin color" with income or other measures of social status were not published at all. As such, the Cuban government's 2018 report to the United Nations (MINREX 2018, 10) heralded the National Office of Statistics' publication Census Data by Skin Color (ONE 2016) as pathbreaking. This publication, however, omitted many important issues in which race has become a significant social marker. Instead, the publication presented a selection of data that served to support the official discourse, according to which the revolution had largely overcome racial discrepancies. The publication's summary concludes that "the differences as to skin color found in this study have low statistical significance. They show no major differentials" (ONE 2016, 4). ${ }^{4}$ As our study will show, such a statement says more about the Cuban National Office of Statistics than about Cuba's contemporary society.

This article proceeds to outline the methodology used for the study's survey, then to present key results on the links between race and inequality, including their underlying causes, as identified in the survey. Three factors that the survey identifies as crucial are highlighted: the impact of past migration patterns and family remittances, the consequences of self-employment and small enterprises in the emergent private sector, and the impact of an additional, foreign citizenship, which has become important since the 2013 liberalization of Cuba's migration policy. The concluding section reflects on the socioracial restratification currently under way in Cuba and asks what implications this may have for policymakers and other actors on and off the island.

\section{METHODOLOGY}

At the heart of this study lies a survey that was taken by 1,049 Cubans from across the island. The survey and accompanying in-depth interviews were conducted by Katrin Hansing and a four-member Cuban research team. ${ }^{5}$ The fieldwork was conducted between January 2017 and April 2018. Despite the constraints involved in conducting surveys in Cuba, Hansing and her team's long-term research experience has shown us that by selecting a cross-section of Cuban society based on age, gender, race, educational background, profession, and territorial or residential location, a semirepresentative survey and reliable results are possible. 
Map 1. Number of Survey Respondents per Province

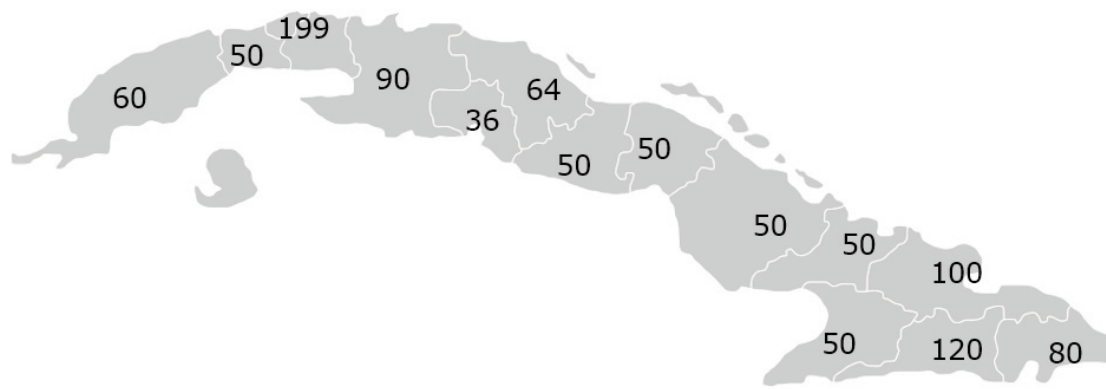

The number of responses for each province, from left to right: Pinar del Río 60, Artemisa 50, La Habana 199, Matanzas 90, Cienfuegos 36, Villa Clara 64, Sancti Spíritus 50, Ciego de Ávila 50, Camagüey 50, Las Tunas 50, Granma 50, Holguín 100, Santiago de Cuba 120, Guantánamo 80.

Whereas most studies of Cuba's changing society tend to be heavily Havanacentric, this survey was carried out nationwide, in urban as well as rural areas and in nearly all provinces (see map 1 ).

The survey comprised 57 questions, usually providing multiple-choice answers, and sometimes including subquestions. ${ }^{6} \mathrm{~A}$ note is due on the terms, categories, and method used in defining the respondents' racial identity. The official Cuban census rejects the term race and instead uses the term skin color (ONE 2016, 7-9). International studies on Latin America and the Caribbean use the terms race or ethnicity/ ethnic group. In this paper these terms are used interchangeably. ${ }^{7}$

The Cuban census allows for three different categories of skin color: white, black, and mulatto (ONE 2016, 4). ${ }^{8}$ In our survey, we used only two categories: white and Afro-Cuban. We are well aware that neither two nor three categories will do justice to the complexity and diversity of racial identities in Cuba. Any such categories cannot be more than a rough approximation, with all the deficits such a reduction of complexity entails. But given the societal relevance race has historically had and continues to have today, coping with the deficiencies of such categories is, in our view, better than not using them at all, and by doing so, being blind to the current social realities.

Our choice to use only two categories—one that includes all Cubans who are phenotypically white, the other all who are phenotypically of African descentstems from the fact that people who are phenotypically of African descent tend to share-in Cuba as elsewhere in the region-similar historical legacies, as well as contemporary social experiences. In Cuba, different terms for people of African descent are used, including afrodescendientes (Afrodescendants), cubanos de origen africano (Cubans of African heritage), and afrocubanola (Afro-Cuban). We find the inclusive term Afro-Cuban most appropriate. This choice is also in line with other prominent scholarship on the matter (Rubiera Castillo and Martiatu Terry 2011; de la Fuente 2008; Helg 1995; Pérez Sarduy and Stubbs 2000). ${ }^{9}$ Moreover, official dis- 
course also tends to group blacks and mulattos together when it speaks of the measures taken to overcome issues of discrimination or underrepresentation (see, e. g., Castro 2018; see also note 24).

As to our method of racial identification: each interviewee was asked to identify him- or herself, and the interviewers were also asked to note down their classification of the person being interviewed. In all 1,049 cases, there was not one single discrepancy between the interviewees' and interviewers' responses.

As mentioned, the survey sought to reflect a semirepresentative cross section of Cuban society. With regard to race and skin color, the Cuban census states that the population is 64 percent white and 36 percent black and mulatto combined (ONE $2016,4)$. Our survey slightly deviates from this ratio, in that it includes 57 percent whites (596 respondents) and 43 percent Afro-Cubans (453 respondents). For gender congruence, our data overlap with the official Cuban data: for 2016, the National Office of Statistics reports 50.19 percent female and 49.81 percent male residents (ONE 2017, 3-4); our survey has 50.14 percent female and 49.86 percent male respondents. On the territorial division, the capital city of Havana accounts for 19 percent of respondents in our survey, which exactly mirrors its share of the national population: 2.13 million out of a total 11.24 million (ONE 2017, 3-4). Similarly, the five easternmost provinces account for 35 percent of the national population (ONE 2017, 3-4) and 36 percent of our survey.

\section{SOCIAL INEQUALITIES Along Racial Lines}

Social and racial inequality have been an integral part of Cuban society since the early days of the Spanish conquest. Africans were brought to Cuba as slaves as early as the sixteenth century but came in especially large numbers in the nineteenth century, when Cuba became a prosperous sugar colony. The introduction of the sugar industry permanently changed the country's social composition, shaping everything from property rights, labor systems, trade, and foreign relations to the island's national culture and identity (Ortiz 1940). As such, it was key in the formation of the island's race, class, and social relations.

After the abolition of slavery in 1886 and in the subsequent republican period (1902-59), race continued to determine people's legal and social rights, as well as their economic status (De la Fuente 1995, 1999; Helg 1995, Fernández-Robaina 1990). Afro-Cubans continued to be discriminated against and systematically excluded from higher positions in employment, public service, and politics and continued to make up the majority of the island's poor and working classes (McGarrity and Cárdenas 1995).

With the triumph of the revolution in 1959, the race question was almost entirely subsumed under a broadly redemptive nationalist and subsequently socialist umbrella. The revolution moved rapidly to dismantle institutional racism and other forms of sociolegal inequality, and the 1976 Constitution explicitly prohibited any discrimination based on race or skin color. Beyond this, the revolutionary govern- 
ment approached the issue of race from a strongly structural perspective, coherent with its Marxist views of history and society. As such, it assumed that with the elimination of private property and class exploitation, racial inequality and discrimination would eventually disappear. The economic, social, and political measures implemented by the revolutionary government mainly benefited people of humble origins, and thereby most Afro-Cubans (McGarrity 1992; Morales Domínguez 2013). By the 1980s, Cuba had become a relatively egalitarian society, with low levels of racial inequality in key areas of professional and social life.

Despite these achievements, the revolution did not specifically target the society's deeply ingrained culture of racism. Instead, the ideological rationale and revolutionary rhetoric of national unity and socialist equality introduced an official silence toward race-related matters, which transformed the issue into a semitaboo topic (De la Fuente 1998; Moore 1988). While race continued to influence social relations in the private realm, the revolution's ideal of egalitarianism was shared by large sectors of the population.

The year 1989 marked a watershed moment. The collapse of Eastern European socialism meant the loss of guaranteed overseas markets and generous Soviet subsidies. It sent Cuba's economy into free fall, from which it has still not emerged. If the state-run economy was a powerful social elevator for the upward mobility of Afro-Cubans in the past, it was precisely the decline of the state economy that reversed this process after 1989. At the depth of the crisis in 1993, the government saw itself forced to legalize the U.S. dollar-essentially to secure the minimum of foreign exchange revenues deemed necessary for survival by tapping into remittances from emigrated relatives (Ritter 1995). ${ }^{10}$ Our survey data clearly reflect how much the socioeconomic divide has widened and how strongly these inequalities overlap with race.

As noted, the National Office of Cuban Statistics does not report on key income inequalities, since its publications provide data only on salaries in the highly devalued Cuban peso (CUP), thereby explicitly excluding hard currency earnings (e.g., ONE 2017, 4). Unsurprisingly, with this type of accounting, official income differences continue to be low. In contrast, our survey asked for income as measured in the convertible peso, or CUC. The results show a remarkable range. While almost three-quarters of the respondents reported an annual income of less than CUC 3,000, 12 percent received between CUC 3,000 and 5,000, and 14 percent reported incomes higher than CUC 5,000 and up to CUC 100,000 annually.

While the data show that a sector of well-off Cubans is emerging, the contrasts are much stronger when we break this data down by race (see table 1). Among AfroCubans, 95 percent report a yearly income below CUC 3,000. In contrast, only 58 percent of white Cubans fall into this lowest income category. In turn, income levels above CUC 5,000 are limited almost exclusively to white Cubans.

Monetary income is not the only factor defining material status, particularly in a socialist country like Cuba, where state subsidies are prevalent. Cuba's welfare provisions have largely been nonmonetary, and although their quality and scope have eroded over time, they still need to be taken into account. As such, despite major 
Table 1. Income and Savings by Race

\begin{tabular}{|c|c|c|c|c|c|c|c|}
\hline $\begin{array}{l}\text { Annual income } \\
\text { in CUC }\end{array}$ & $<3,000$ & $\begin{array}{c}3,001- \\
5,000\end{array}$ & $\begin{array}{l}5,001- \\
10,001\end{array}$ & $\begin{array}{l}10,000 \\
20,000\end{array}$ & $\begin{array}{c}20,001- \\
40,000\end{array}$ & $\begin{array}{l}40,001- \\
60,000\end{array}$ & $>60,000$ \\
\hline \multicolumn{8}{|l|}{ Percent } \\
\hline Total & 74.2 & 11.9 & 3.3 & 2.0 & 2.8 & 2.4 & 0.8 \\
\hline White & 58.5 & 18.3 & 8.6 & 4.4 & 4.2 & 4.7 & 1.3 \\
\hline Without remittances & 24.4 & 13.0 & 13.3 & 8.9 & 17.0 & 18.5 & 5.9 \\
\hline With remittances & 68.5 & 20.2 & 7.2 & 3.0 & 0 & 0 & 0 \\
\hline Afro-Cuban & 94.9 & 3.5 & 0.9 & 0.7 & 0 & 0 & 0 \\
\hline Without remittances & 97.2 & 1.5 & 0.3 & 0.9 & 0 & 0 & 0 \\
\hline With remittances & 89.1 & 6.6 & 2.3 & 0 & 0 & 0 & 0 \\
\hline Savings in CUC & 0 & $1-100$ & $\begin{array}{c}101- \\
250\end{array}$ & $\begin{array}{c}251- \\
500\end{array}$ & $\begin{array}{l}501- \\
3,000\end{array}$ & $>3,000$ & \\
\hline \multicolumn{8}{|l|}{ Percent } \\
\hline Total & 6.8 & 26.8 & 17.9 & 19.2 & 17.4 & 11.9 & \\
\hline White & 1.3 & 11.0 & 19.1 & 23.6 & 25.1 & 19.9 & \\
\hline Afro-Cuban & 14.1 & 47.8 & 16.4 & 13.2 & 7.2 & 1.3 & \\
\hline
\end{tabular}

Source: Authors'survey data

cutbacks, the food-rationing system still distributes basic food supplies at almost symbolic CUP prices. Education and healthcare are free, and public transportation, as well as arts, cultural, and sports events, are heavily subsidized. Also, given that most Cubans own their own home and rents are subsidized, housing costs are not as central a concern as elsewhere. However, because most state-run and private businesses have become CUC-based, it has become almost impossible for ordinary Cubans to satisfy their daily needs with their CUP salaries.

The increased monetization of socioeconomic affairs is a key ingredient of Cuba's ongoing economic reform process. Access to a bank account is a good indicator of how prepared people are for this. Here, too, our survey provides strong evidence of the increasing race-based inequalities. Among white Cubans, 50 percent of respondents reported having a bank account; among Afro-Cubans, this was a mere 11 percent (see table 2 ).

Savings, in bank accounts or elsewhere, are another important indicator of socioeconomic status. The level of savings shows not only how prepared people are to face adverse material circumstances but also how able they are to take advantage of possibilities in the market sector of the Cuban economy. More than 62 percent of AfroCubans but only 12 percent of whites in our survey report savings of less than CUC 100 (see table 1). On the other end of the spectrum, while 45 percent of white Cubans have savings above CUC 500, this is the case for only 8 percent of Afro-Cubans.

The Internet came late to Cuba; it is monitored by the state and is very expensive and slow (Hoffmann 2004; Periodismo de Barrio 2018). Nevertheless, it is a crucial indicator of how well people are connected to modern communications and to 
Table 2. Selected Monetary and Social Indicators by Race (percent)

\begin{tabular}{lcc}
\hline \hline & White & Afro-Cuban \\
\hline Bank account holder & & \\
$\quad$ Yes & 50.4 & 11.5 \\
No & 49.6 & 88.5 \\
Internet access & & \\
$\quad$ Does not have & 25.2 & 70.0 \\
In public areas & 62.1 & 27.8 \\
At home & 12.7 & 2.2 \\
Travel abroad & & \\
Yes & 30.9 & 3.3 \\
No & 69.1 & 96.7 \\
Remittance receiver & & \\
Total & 78.1 & 21.9 \\
Yes & 77.3 & 28.5 \\
No & 22.7 & 71.5 \\
Reason for not receiving remittances & & \\
I'm fine & 62.2 & 0.3 \\
Family abroad does not send & 9.6 & 14.8 \\
I do not have family abroad & 28.1 & 84.9 \\
\hline \hline
\end{tabular}

Source: Authors's survey data

the social and economic benefits these can bring. There are no official data that provide information about the relationship between Internet access and racial identity, but our survey reveals a profound cleavage (see table 2). Among Afro-Cubans, 70 percent responded that they had no Internet access whatsoever; among whites, this was down to 25 percent. Almost two-thirds of white Cubans do have access via public areas, such as the Wi Fi zones in public parks; for Afro-Cubans, this is a mere 28 percent. Internet access at home is still low in all sectors of society but again, much lower among Afro-Cubans. ${ }^{11}$

A key step undertaken under Raúl Castro's leadership was the migration law reform in 2013, which eliminated the domestic administrative obstacles for Cubans when leaving the island. Since then, travel has increased greatly. In a context in which the petty import business into Cuba is booming (Ravsberg 2018), travel possibilities constitute an important material asset. In our survey, 31 percent-almost one-third-of white Cubans reported having traveled since the migration law reform; among Afro-Cubans, this total was a mere 3 percent (see table 2).

Whether we look at income, access to a bank account, savings, Internet connectivity, or travel abroad, our survey results show that the inequalities that have opened up in Cuban society are profoundly marked by race. We now turn to the driving forces behind this process. 


\section{Past Migration Patterns AND THE IMPACT OF FAMILY REMITTANCES}

Migrant remittances have become an important source of external finance in much of the developing world. While one line of research has pointed to their positive effects, including the reduction of poverty, the provision of social security, and overall development (Orozco 2013; Ratha 2005), other studies have underscored their detrimental impact, stressing that they produce dependencies and lead to further outward migration (Dagher et al. 2008; Kapur 2004).

Although a latecomer to the group of remittance-receiving countries, Cuba's intake from money transfers has more than doubled, from an estimated US\$1.5 billion in 2008 to US\$3.7 billion in 2018 (Havana Consulting Group 2019). This is a huge portion of the island's yearly hard currency intake. To this should be added a large amount of remittances in kind (mostly consumer goods) —in 2018 estimated to be almost as high as the monetary remittances (Havana Consulting Group 2019). ${ }^{12}$ However, the distribution of remittances in Cuban society is atypical for a country of the Global South, given the historic migration patterns on which these remittances are based.

In Mexico, Central America, and other countries in the region, it has typically been the lower strata of society that have emigrated to the United States. In contrast, in Cuba the 1959 revolution sparked the exodus of hundreds of thousands of mostly white upper- and middle-class Cubans, who had lost their power, property, privileges, and businesses. Between 1959 and 1973, more than half a million Cubans emigrated to the United States, most of whom settled in South Florida, especially Miami. In the following decades, other migrant cohorts enlarged the Cuban émigré community. Thanks to generous U.S. federal assimilation aid, the emigrants' social backgrounds, and their own entrepreneurial spirit, they became one of the most successful immigrant communities in post-World War II history (Portes and Stepick 1993) and built one of the most powerful political lobbies in U.S. foreign policy (Portes 2007).

Despite the strong political rifts, the longstanding economic embargo, and deepseated emotional wounds, the two Cuban communities-on the island and in the U.S. diaspora-have been and continue to be much more closely connected than is usually publicly acknowledged. A wide range of transnational social, cultural, and religious ties have emerged over the past decades, of which family visits and the sending of remittances are the most visible (Cervantes-Rodríguez 2010; Hansing and Mahler 2003, 2005; Hoffmann 2005; Pedraza 2007).

The Cuban émigré community today represents all ages, provinces on the island, socioeconomic and educational backgrounds, religious affiliations, and political views. In many ways, the Cuban diaspora reflects Cuba's own diversity, with the exception of one key aspect; namely, the island's racial composition. According to U.S. census data, of the more than 1.8 million Cuban-Americans, 85 percent are white (U.S. Census Bureau 2011).

This strongly racialized migration pattern has immediate consequences for remittances. Since the 1990s, a number of surveys have shed light on the impact and 
uses of remittances in Cuba (Hansing and Orozco 2009, 2014), but Sarah Blue's 2007 study is the only one that has specifically focused on the relationship between remittances and race. However, as mentioned, her research focused on only a few neighborhoods in Havana, and it did so in 2000, when the volume of remittances was still much lower and private business possibilities much fewer. Since then, no substantial empirical research on the links between remittances and race has been undertaken.

Our survey confirms that remittances flow mainly along family lines. In fact, only 2 percent of respondents stated that the sender of their remittances was a friend, whereas for all others it was a family member. Among white respondents, 93 percent had a family member abroad; among Afro-Cubans, only 34 percent did. This translates into unequal access to remittances. In our survey, a total of 56 percent of respondents received remittances. Of these remittance receivers, 78 percent were white and only 22 percent Afro-Cuban (see table 2 ). We could call this a form of unequal, discriminatory economic development through remittances.

However, the most striking racial divide comes from the 44 percent of respondents who did not receive remittances at all. When asked why they did not receive remittances, 85 percent of Afro-Cubans responded that they did not have family abroad, while among whites this was the case for only 28 percent (see table 2). Among Afro-Cubans, the remaining 15 percent said that their relatives abroad do not send money; for whites, this was 10 percent. However, there was a third category: 62 percent of the whites without remittances said they do not receive any because they "are fine" (estoy bien). In other words, they do not need monetary support from their family abroad. Among Afro-Cubans, not a single respondent answered in this manner.

The general assumption is that people who receive remittances are better off than those who do not. This is also true in the case of Afro-Cubans. The 28 percent of Afro-Cubans who received remittances reported a slightly higher average income than those who did not (see table 1). However, the situation is different for white Cubans. Here, somewhat counterintuitively, those who received remittances reported significantly lower incomes (on average less than CUC 5,000 annually) than those who did not (on average more than CUC 8,000).

We find the explanation for this when we take a closer look at the group of white Cubans without remittances (see table 1). In all other categories-AfroCubans with or without remittances and whites with remittances- the great majority reported an income below CUC 3,000, with declining numbers for higher incomes. For whites without remittances, however, we see a camel-back pattern: a first "hump" of approximately 24 percent for the lowest income category, below CUC 3,000, but then a second "hump" of a combined 35 percent reporting incomes of either CUC 20,000-40,000 or CUC 40,000-60,000.

In other words, among whites who do not receive remittances, those who are relatively poor are a minority group, while a larger number is what we could call living above the remittance line. Given that their incomes are sufficiently high, they do not need money transfers from abroad to support them. 
Table 3. Logistic Regression Coefficients

\begin{tabular}{|c|c|c|c|c|}
\hline $\begin{array}{l}\text { Dependent Variable: } \\
\text { Annual Personal Income } \\
\text { Variables }\end{array}$ & $\begin{array}{c}\text { (1) } \\
\text { Group 1 }\end{array}$ & $\begin{array}{c}\text { (2) } \\
\text { Group } 2\end{array}$ & $\begin{array}{c}\text { (3) } \\
\text { Group } 3\end{array}$ & $\begin{array}{c}(4) \\
\text { Group } 4\end{array}$ \\
\hline $\begin{array}{l}\text { Group 1: Afro-Cubans without } \\
\text { remittances }\end{array}$ & $\begin{array}{l}-2.948^{* * *} \\
(0.359)\end{array}$ & & & \\
\hline Group 2: Afro-Cubans with remittances & & $\begin{array}{r}-0.953^{*} \\
(0.353)\end{array}$ & & \\
\hline Group 3: Whites without remittances & & & $\begin{array}{l}2.200^{* * *} \\
(0.222)\end{array}$ & \\
\hline Group 4: Whites with remittances & & & & $\begin{array}{l}0.614^{* * *} \\
(0.168)\end{array}$ \\
\hline Age $=1,17-30$ & (base) & (base) & (base) & (base) \\
\hline Age $=2,31-40$ & $\begin{array}{l}1.421^{* * *} \\
(0.321)\end{array}$ & $\begin{array}{l}1.187^{* * *} \\
(0.311)\end{array}$ & $\begin{array}{l}{ }^{*} \quad 1.187^{* * *} \\
(0.327)\end{array}$ & $\begin{array}{l}1.266^{* * *} \\
(0.315)\end{array}$ \\
\hline Age $=3,41-50$ & $\begin{array}{l}1.649^{* * *} \\
(0.318)\end{array}$ & $\begin{array}{l}1.410^{* * *} \\
(0.306)\end{array}$ & * $\begin{array}{l}1.296^{* * *} \\
(0.322)\end{array}$ & $\begin{array}{l}1.517^{* * *} \\
(0.311)\end{array}$ \\
\hline Age $=4,51-60$ & $\begin{array}{l}1.228^{* * *} \\
(0.322)\end{array}$ & $\begin{array}{l}1.393^{* * *} \\
(0.313)\end{array}$ & $\begin{array}{l}* 1.150^{* * *} \\
(0.330)\end{array}$ & $\begin{array}{l}1.412^{* * *} \\
(0.319)\end{array}$ \\
\hline Age $=5,61+$ & $\begin{array}{r}-0.782^{*} \\
(0.468)\end{array}$ & $\begin{array}{l}-0.521 \\
(0.461)\end{array}$ & $\begin{array}{l}-0.572 \\
(0.501)\end{array}$ & $\begin{array}{l}-0.628 \\
(0.474)\end{array}$ \\
\hline Gender $=1$, Female & $\begin{array}{c}-0.642^{* * *} \\
(0.176)\end{array}$ & $\begin{array}{c}-0.525^{* * *} \\
(0.168)\end{array}$ & $\begin{array}{c}-0.424^{* *} \\
(0.177)\end{array}$ & $\begin{array}{c}-0.611^{\text {*** }} \\
(0.171)\end{array}$ \\
\hline Education $=1$, University & $\begin{array}{l}1.607^{* * *} \\
(0.176)\end{array}$ & $\begin{array}{l}1.826^{* * *} \\
(0.166)\end{array}$ & * $\begin{array}{c}1.651^{* * *} \\
(0.179)\end{array}$ & $\begin{array}{l}1.820^{* * *} \\
(0.168)\end{array}$ \\
\hline Constant & $\begin{array}{l}-2.065^{* * *} \\
(0.286)\end{array}$ & $\begin{array}{l}-2.549^{* * *} \\
(0.279)\end{array}$ & * $\begin{aligned}-2.866^{* * *} \\
\\
(0.297)\end{aligned}$ & $\begin{array}{l}-2.930^{* * *} \\
(0.293)\end{array}$ \\
\hline Observations & 1,047 & 047 & 1,047 & ,047 \\
\hline Wald chi ${ }^{2}$ & 198.4 & 175.3 & 243.5 & 181.3 \\
\hline Degrees of freedom & 7 & 7 & 7 & 7 \\
\hline Prob $>\mathrm{chi}^{2}$ & 0 & 0 & 0 & 0 \\
\hline
\end{tabular}

${ }^{* * *} \mathrm{p}<0.01,{ }^{* *} \mathrm{p}<0.05,{ }^{*} \mathrm{p}<0.1$

Robust standard errors in parentheses.

Annual personal income > CUC 3,000 (= US\$)

Source: Authors's survey data

The logistic regression on income for the four social groups that result from combining race and remittances underscores these findings (see table 3). Whites without remittances have the highest positive coefficient for having an income above CUC 3,000, followed by whites with remittances. Afro-Cubans, in contrast, show a negative correlation-less markedly if they have access to remittances, and more strongly if they do not. This also holds true when we control for age, gender, and educational level. The table shows that these factors do have a significant impact on 
income, but it is a very similar one within each of the four categories. The much bigger difference is not within but between the categories of race and remittances.

\section{SELF-EMPLOYMENT}

\section{AND SMALl ENTERPRISES}

When, in the 1990s, the U.S. dollar was legalized in Cuba and remittances started to pour in, these mainly served, as they have elsewhere, as a private social safety net. Sarah Blue's research (2007), conducted in 2000, showed how access to remittances translated into higher levels of consumption. This is still the case for many, but the current economic reform process has given remittances a new significance that goes beyond these differences in daily consumption.

In the mid-1990s, when the first legal spaces for self-employment, such as private restaurants (paladares) and room rentals, were opened up, these remained limited and narrowly controlled by the state (Ritter 1998). Since 2006, under Raúl Castro's leadership, the gradual opening up of private sector activities has picked up speed and become part of the government's long-term strategy (PCC 2011; Hoffmann 2016). These reforms have changed Cuba's economic landscape, turning private vendors and services, as well as cafeterias, into a regular part of daily life. Remittances now no longer merely serve as a private safety net but have become a key source of capital for investment.

The National Office of Statistics report on the census data according to skin color does address what it calls the "participation in the so-called emergent sector of the economy" (ONE 2016, 37). For those working as self-employed, it does find higher participation of whites than Afro-Cubans. The self-employed make up 8.6 percent of whites versus 6.4 percent of blacks and 6.6 percent of mulattoes. The publication concludes that there is "a certain difference in favor of whites" (ONE 2016, 37)..$^{13}$

In the official statistics, this imbalance is still relatively modest. But this is only the case because the National Office of Statistics publication does not distinguish between different types of private sector activities or between the different levels of income that they generate. Actually, there is enormous diversity in terms of what falls under so-called private sector activities, ranging from street vendors, who sell peanuts for a few pesos cubanos (CUP), to people who own and rent out private rooms or entire apartments to foreigners in hard currency, or CUC. In contrast to the National Office of Statistics data, our survey did take these differences in private sector income into account.

The Cuban government has long insisted on keeping private economic activities small-scale. The very term self-employed work (trabajo por cuenta propia), rather than small or medium enterprises, keeps this sector linguistically in the realm of workers, not entrepreneurs. In practical and legal terms, there are also numerous restrictions to prevent private sector businesses from growing "too much." As a result, most activities are indeed small-scale, and while they generate higher incomes than the state sector, most people earn a fairly modest living. 
Table 4. Business Sales and Type of Business by Race

\begin{tabular}{|c|c|c|c|c|c|c|c|c|c|}
\hline \multicolumn{3}{|c|}{$\begin{array}{l}\text { Monthly sales of the current } \\
\text { business in CUC }\end{array}$} & \multirow[t]{2}{*}{$1-250$} & \multicolumn{2}{|c|}{$251-500$} & $501-1,000$ & \multicolumn{2}{|c|}{$1,001-3,000$} & \multirow[t]{2}{*}{$>3,000$} \\
\hline \multicolumn{8}{|c|}{ Percent } & & \\
\hline White & & & 29.8 & & 2.2 & 17.3 & 17 & 7.8 & 12.9 \\
\hline Afro-Cubar & & & 77.0 & & 6.4 & 6.6 & c & 0 & 0 \\
\hline $\begin{array}{l}\text { Type of } \\
\text { business }\end{array}$ & $\begin{array}{c}\text { Room } \\
\text { rental/ } \\
\text { B\&B }\end{array}$ & Restaurant & $\begin{array}{r}\text { Sim } \\
\text { t gastro }\end{array}$ & & $\begin{array}{l}\text { Beauty } \\
\text { services }\end{array}$ & $\begin{array}{c}\text { Produc- } \\
\text { tion }\end{array}$ & $\begin{array}{c}\text { Services } \\
\text { (crafts) }\end{array}$ & Vendor & $\begin{array}{l}\text { Other } \\
\text { services }\end{array}$ \\
\hline \multicolumn{10}{|l|}{ Percent } \\
\hline White & 30.0 & 4.4 & 13 & & 13.7 & 8.0 & 10.2 & 5.8 & 14.2 \\
\hline Afro-Cuban & 1.6 & 0 & 14 & & 11.5 & 6.6 & 19.7 & 27.9 & 18.0 \\
\hline
\end{tabular}

Source: Authors'survey data

Our survey reflects this. Of the 286 respondents undertaking private sector activities, more than 60 percent reported sales of less than CUC 500 per month. However, the racialized stratification within this sector becomes evident when these data are disaggregated along racial lines (see table 4). Of the Afro-Cubans engaged in private sector activities, 77 percent have sales below CUC 250 per month; among whites this is a mere 30 percent. Among high-revenue businesses we find the opposite. Almost half of the self-employed whites have monthly sales above CUC 500, compared to a mere 7 percent among self-employed Afro-Cubans. Almost a third of white Cubans in this sector reported monthly sales above CUC 1,000; not a single Afro-Cuban did.

The differences in income in Cuba's private sector depend largely on the type of activities the self-employed engage in. Two types of businesses can be considered high-revenue activities: the room and apartment rentals that have grown at par with the boom in tourism, and the paladares, which cater mainly to tourists and to the small but growing number of relatively high-income Cubans. Because the laws do not allow the leasing or acquisition of state property for these activities, both room rentals and restaurants depend crucially on the availability of large private homes.

Here, the issue of prerevolutionary property is significant. After 1959, the revolutionary government confiscated private businesses and seized all rental housing properties. Under the Urban Reform Law of 1960, an individual was allowed to keep one private home (house or apartment) and one vacation home, at the beach or in the country (Coyula and Hamberg 2004, 18). Until the 1990s, this meant that certain individuals and families were privileged in terms of their housing situation, but not much more. However, with the legalization of private room and home rentals and restaurants in the 1990s, the grand mansions and spacious apartments from the prerevolutionary era became the crucial base for entering and benefiting from the most lucrative segments of the new market economy. Given the racialized stratification of Cuba's pre-1959 society, the access to such real estate-and hence 
the possibility of opening a restaurant or a bed and breakfast—has starkly disfavored Afro-Cubans.

This "property bias" was given further fuel by Law 288, which, as part of Raúl Castro's economic reform agenda, legalized the buying and selling of private property. This recommodification evidently favors prerevolutionary elites who kept their property, as well as those revolutionary cadres who, after 1959, were allotted confiscated property to live in. ${ }^{14}$ It also favors a third, often overlapping sector; namely, those with family members abroad willing and able to finance real estate acquisitions on the island. ${ }^{15}$ In racial terms, this circumstance again tilts strongly in favor of white Cubans.

Our survey data on occupations in the emergent private sector provide evidence of the resulting racial imbalances. Among self-employed Afro-Cubans, the largest share is that of petty vendors ( 28 percent), followed by craftspeople (20 percent) and small-scale gastronomic services (15 percent) (see table 4). In our survey, no AfroCuban owns a private restaurant, and only one respondent ( 2 percent) reported renting out accommodations. In contrast, among whites, renting private accommodation is the single biggest category (30 percent); restaurants are relatively few, at only 4 percent, but this is a category in which Afro-Cubans are entirely absent. Petty vendors, the number one category among Afro-Cubans, accounts for only 6 percent of white respondents. ${ }^{16}$

If we single out the two categories identified as high-revenue activities_-private accommodations and restaurants — a stunning 98 percent of businesses are in the hands of white Cubans. Most of these people report that they do not receive remittances. In fact, this is the core of those who do not receive remittances because, as they say, "they are fine." There may, however, also be a semantic issue at work. The concept of remittances (remesas) usually refers to a relatively small amount of money that is sent to an individual or a family to help them cover their basic monthly costs. The Cubans who "are fine" may, in fact, be receiving money from relatives abroad but may not see this as remittances; instead, they may view it as startup capital or as a joint "family investment" to purchase a house or car, renovate a home, or start a business. The new economics of labor migration conceive of "remittances as an intrafamily loan arrangement" (Poirine 1997), and this is the prototypical Cuban version of it.

\section{IMPACT OF ADDITIONAL FOREIGN CitIZENSHIP}

As we have seen, transnational links based on past racialized migration patterns have had an enormous impact on the restructuring of Cuban society currently taking place. As part of this, another factor comes into play; namely, the ability or inability to obtain a second, foreign citizenship.

This issue gained prominence in Cuba when, in 2007, a Spanish law-colloquially called the grandchildren's law (ley de nietos) — gave the right to acquire Spanish citizenship to whoever could claim to have a Spanish grandparent. ${ }^{17}$ In many 
countries, people of Spanish descent took advantage of this possibility to obtain a Spanish — and thereby an EU-passport, but in Cuba the impact was enormous. As of 2018, more than 110,000 Cubans had become Spanish citizens under this law, and another 70,000 applications were still being processed (Reigosa González 2018; De Blas 2018).

In our survey, 68 of 1,049 respondents reported holding a second citizenship. Of these, 85 percent held Spanish citizenship; the remainder were split among different nationalities, acquired mostly through marriage. ${ }^{18}$ This underscores the crucial impact of Spain's "grandchildren's law." Because it is based on Spanish ancestry, it is of little surprise that access to Spanish citizenship is, exceptions apart, a privilege of white Cubans. In our sample, there was not a single dual citizen among the Afro-Cubans.

A second citizenship is of great value in many parts of the world, as the spread of citizenship-by-investment programs shows (Shachar 2017). In Cuba, the privileges of an EU passport are immediately tangible: such a passport is the key to international mobility. Since the migration law reform eliminated the administrative hurdles for leaving the island, obtaining a visa to enter Europe, the United States, or most other countries has become the bottleneck constraining Cubans' travel possibilities, not Cuban regulations. However, Cubans with an EU passport bypass these visa requirements. The survey data show how much more international mobility takes place among dual citizens: 98 percent had traveled abroad since the 2013 migration law, compared to a mere 14 percent of those with only Cuban citizenship.

Travel possibilities are the key resource for the flourishing petty import business, which brings everything from clothes to cellphones and from makeup to air conditioners into the country. In addition, an EU passport paves the way to opening a bank account abroad, which is of much value for transnational business, renting apartments, or getting a credit card. The privileges also extend to the family, as spouses of Spanish citizens are given the right of residence and, over time, can also obtain citizenship.

In all survey questions on material status, the group of Cubans with a second citizenship came out on top. Regarding income, 47 percent of dual nationals were in the highest income categories of CUC 20,000 or more per year, compared to less than 3 percent of those with only Cuban citizenship. Except for one respondent, all dual nationals had family abroad; all others either received remittances or did not need them (estoy bien). In spite of the high number of senior citizens among the dual nationals, more than half of them had their own business, which, in four out of five cases, meant one of the two high-revenue businesses, renting accommodations or running a restaurant.

It should be noted that Cuba's 1976 Constitution was explicit in not allowing Cubans to hold a second citizenship. Article 32 states, "Dual citizenship is not admitted. As a consequence, if a foreign citizenship is acquired, the Cuban citizenship will be lost" (República de Cuba 1992). ${ }^{19}$ In practice, however, over the years it became fully accepted that Cubans held a second passport and made use of it when they were outside the country. The 2019 constitutional reform gave this practice constitutional standing in the reformed article on citizenship, now Article 36, 
which is explicit in stating, "Acquisition of another citizenship does not imply loss of the Cuban citizenship" (República de Cuba 2019, Art. 36). ${ }^{20}$

While the group of Cuban dual nationals is not significant in number, it is central to who makes up the top echelons of Cuba's new social structure. In a context in which international mobility is a key economic asset, these individuals are among the major players. The impact is particularly striking because the coveted EU passport is accessible almost exclusively to a social group that is already better off; namely, white Cubans with family abroad. It is a privilege that comes on top of, and reinforces, an already favorable social status.

\section{CUBA's SOCIORACIAL RESTRATIFICATION: CONCLUSIONS AND POLICY IMPLiCATIONS}

As this article has shown, social and racial inequalities are rapidly increasing in Cuba. Whereas Blue, on the basis of her 2000 survey data, had already diagnosed an "erosion of racial equality" (Blue 2007), this has now taken on a new character: not only have living standards become less equal, but a comprehensive structural reconfiguration of Cuban society is taking place.

From a comparative perspective, the socioeconomic cleavages on the island are not as profound, and the racial imbalances are not yet as deeply engrained, as in numerous other Latin American countries. The universal coverage of social services, including education and health, continues to be-despite their eroding quality-an important factor in maintaining social cohesion. Also, the political bureaucracies of the party, state, and security apparatus provide avenues of social ascension for AfroCubans, as do sports, the arts, and culture.

Moreover, recently the government stepped up its commitment to give AfroCubans a stronger presence in state leadership functions. Most visibly, of the six vice presidents of the Díaz-Canel government named in the National Assembly meeting of April 2018, three are Afro-Cuban, including the first vice president. In his closing speech at the event, Raúl Castro explicitly framed this as part of what he called the "battle for proportions" (political scientists would speak of "descriptive representation"), highlighting that "in the new Council of State blacks and mulattos make up 45.2 percent," and among the National Assembly deputies, 40.49 percent (Castro 2018). ${ }^{21}$

Nevertheless, given that overcoming social inequalities and racial discrimination has been at the very core of the revolutionary project, the growing social and racial restratification described in this study is dramatic and a source of enormous popular frustration. ${ }^{22}$ Moreover, it has a number of immediate political implications.

For one, the increasing social inequalities lend urgency to the reform of Cuba's social welfare system. At present, the system is based on the principle of universal, equal coverage. As such, for example, all Cubans receive the highly subsidized food provisions via a ration system, regardless of whether they need them or not. The issue of moving from a universal ration card system to a targeted social safety program based on need has been on Cuba's reform agenda for many years without 
being tackled (Carranza Valdés et al. 1996). Postponing its implementation has not helped to curb social inequalities.

There is much at stake. For the socialist government, rising inequalities touch on a key pillar of political legitimacy. Although Raúl Castro's reform agenda bid farewell to the excessive egalitarianism of the past, the state and party leadership still claim to be the guardians of social justice and societal cohesion. A central instrument in this regard has been to put the brakes on the growth of the private sector; for instance, by restricting the size of businesses, freezing the licensing process, closing down restaurants, or cracking down on middlemen with much fanfare. However, it is precisely this attitude that has prevented the reform process from gaining sufficient dynamism to propel economic development. As Cuban economist Ricardo Torres (2018) comments, "We have almost always tried to solve the issue of equality by equalizing downward."

Not only is the brake on the private sector at odds with the hopes of economic growth through reform, it also fails to recognize that the root cause of the widening social gap is not the opening of small businesses but the massive decline of the state sector. Real wages are still at an estimated 39.3 percent of what they were in $1989 .{ }^{23}$ The state economy, which used to be the great social elevator, has now had the reverse effect. The crucial issue, then, is not so much to curb the growth of the private sector but to overcome the inefficiencies of the state sector in order to allow real wages to regain purchasing power.

The debate on social inequalities, even if it suffers from a lack of data, has by now become an issue of public discourse in Cuba. But the racial connotations of these inequalities are largely being dismissed. Scholars, as well as activists on the island, have called for the National Office of Statistics to publish data on the relationship between race and social inequality in more meaningful ways. In the words of the Afro-Cuban scholar Esteban Morales Domínguez: "The Cuban population is treated as a homogenous mass. This is an error of incalculable magnitude . . 'black skin color' has always been a category of social differentiation-a category that is not taken into consideration by our national statistics apparatus" (2018). ${ }^{24}$ This is what our research has addressed. Its analysis shows how strongly the prerevolutionary racialized social structure is shaping the current reproduction of social inequalities. With much less access to financial capital, goods, and mobility, Afro-Cubans are being clearly disadvantaged. In the current restratification of Cuban society, this racial bias is turning back one of the proudest historic achievements of the Cuban Revolution.

\section{NoTES}

The authors thank the team of Cuban colleagues for their outstanding work in carrying out the survey on the island, Ana Lluberes and Simone Gotthardt for their research assistance in the elaboration of the data, and the four anonymous LAPS reviewers for their thoughtful comments. All translations are by the authors.

1. In mid-2019 the government announced sweeping wage and pension increases for almost 1.5 million state employees, which would bring the average salary up to 1,067 pesos, according to the government (Díaz-Canel 2019). However, although the measure was accom- 
panied by a wide range of price controls, fears are that this increase in state expenditure might have inflationary effects that would eventually "eat up" the increase in real terms. As of this writing, it is too early to tell; therefore we decided not to update the 2018 average salary value and its USD equivalent.

2. Díaz-Briquets (2008) used a telephone survey to assess the impact of remittances on households in Cuba, finding a higher inclination of whites than Afro-Cubans to receive remittances (156). However, the author himself is aware of the limited validity of the results from this survey method, conceding that "the telephone survey results cannot be ascribed to the Cuban population at large as they are only applicable to the population of telephone land line subscribers. A reasonable assumption is that the vast majority of phone lines in Cuba are located in urban areas and among economically better-off households" (DíazBriquets 2008, 156).

3. Official data for Cuba's Gini index based on CUP indicate that it rose from .24 in 1986 to .38 in 2000, when the last figures were made available (Frank 2018).

4. Orig. Los diferenciales por color de la piel encontrados en este estudio son poco significativos desde el punto de vista estadístico. No aparecen marcados diferenciales.

5. The Cuban research team included an Afro-Cuban female anthropologist from Santa Clara, who administered the surveys in the center of the island; a white Cuban female sociologist and an Afro-Cuban male anthropologist from Santiago de Cuba, who worked in Cuba's eastern provinces; and a white female economist from Havana who, together with Katrin Hansing, worked in Havana and in the western provinces. Thanks to years of cooperation with this team in previous surveys (Hansing and Orozco 2011; Hansing and Orozco 2014), the project could build on extraordinarily strong relations of trust, which enabled the research to overcome the challenges of conducting surveys in Cuba. The team was trained to select survey subjects to be as representative of the key social categories of Cuban society as possible.

6. The main categories (which included numerous subcategories) were Personal/Demographic Data; Remittances; Current Private Business; Future Private Business; Interest in Investing in an Economic Activity; Banking Services, Savings, and Other Financial Activities; Citizenship, Migration, and Travel.

7. We adhere to the statement on race adopted by the American Anthropological Association: http://www.aaanet.org/stmts/racepp.htm. As such, we understand the term race (racial and racism) to be a social construction and use it as such throughout this text. Please note that the word race and its associations are used hereafter without italics.

8. Until the 2002 census, it was the interviewer who defined what racial category identified individuals. Since 2012, the method has been changed, and now allows for the interviewee to identify him- or herself (ONE 2016, 10). According to the National Statistics Office, there was no bias by method, as evidenced in the fact that there was no significant change in the data following the change of method (ONE 2016, 10).

9. In the current debate on the island, Abreu (2014) has emphatically argued for the use of the term afrocubanola, as it represents a "theoretic space which the tradition of the antiracist and decolonizing school of thought in Cuba has constructed throughout the twentieth century." (Orig: espacio teórico que la tradición del pensamiento antirracista y descolonizador cubano construyó a lo largo del siglo XX.) In 2019, an open letter by the Afro-activist Cofradía de la Negritud (Black Brotherhood) to President Díaz-Canel similarly took issue with what it sees as the government's rejection of the term Afro-Cuban, linked to its insistence on the "non-existence of structural or institutional racial discrimination in Cuba" (Mesa Carbonell 2019). 
10. The Cuban leadership certainly was aware that the legalization of the U.S. currency brought about undesirable effects but still was inevitable. In announcing the step, Fidel Castro himself explicitly stated, "we do not like some of these measures" (Castro 1993, orig. algunas de estas medidas no nos gustan).

11. These data are, of course, a snapshot. The introduction of G3 mobile Internet services on the island in December 2018, as well as the legalization of private WiFi in 2019, expanded Internet access among Cubans - though probably reinforcing instead of diminishing inequalities of access.

12. Nova González (2019) provides ample evidence of the different forms these remittances in kind take.

13. Orig.: cierto diferencial en favor de los blancos.

14. In this context, Bastian $(2018,125)$ speaks of the beneficiaries as "Cuba's two historical ruling classes: the children and grandchildren of prerevolutionary elites who remained in Cuba after the Revolution, and the descendants of revolutionary leaders."

15. In fact, prices of the transactions on the island are often underdeclared to minimize taxation; it is not rare that the undeclared part of the transaction takes place offshore, passing from one Miami bank account to another.

16. Private taxi and transport services are another sector in which prerevolutionary property — and hence pre-1959 ethnic hierarchies—weigh heavily.

17. The official name is Historical Memory Law (Ley de Memoria Histórica). Its main purpose was to heal wounds from the country's civil war and to give recognition to the victims of the Franco dictatorship (Gobierno de España 2007). Granting citizenship to the grandchildren of Spanish émigrés was not at the core but merely an "additional disposition" of the law. While there were emotional debates about the law as such, this aspect was hardly discussed in Spain when the law was passed (Golías Pérez 2016, 83).

18. Another rapidly growing group of dual citizenship holders are Cubans who have emigrated and become naturalized abroad and then decided to repatriate to Cuba. This group, called repatriados (repatriated), is a recent phenomenon, and according to the director of Cuban Consular Services, more than forty thousand applications for repatriation have been filed since 2013 (Gamez Torres 2018). Many of these repatriated Cubans are, in part, reclaiming their Cuban citizenship in order to buy property on the island, a right that is still exclusively reserved for Cuban residents.

19. Orig. No se admitirá la doble ciudadanía. En consecuencia, cuando se adquiera una ciudadania extranjera, se perderá la cubana. cubana.

20. Orig. La adquisición de otra ciudadanía no implica la pérdida de la ciudadanía

21. Orig. todavía nos queda la batalla de la proporción en los aspectos no solo numéricos, como dije, sino cualitativos, en lugares decisorios. . . . Tres mujeres fueron elegidas vicepresidentas del Consejo de Estado, dos de ellas negras. ... [En la composición del Consejo de Estado] la representación de negros y mestizos alcanzó el 45,2 per ciento. . . [entre los diputados a la Asamblea Nacional] la representación de negros y mestizos alcanzó el 40,49 per ciento, y asi debe seguir.

22. The issue of Afro-Cuban discontent on the island surfaced prominently in international media with the publication of an article by Roberto Zurbano in the New York Times (2013). It also kicked off a controversial debate on the island itself, which has been documented in part in a special issue of the Afro-Hispanic Review (vol. 33, no. 1, Spring 2014). The so-called Zurbano incident is also the point of departure for West-Durán (2018) to critically discuss Cuba's "racial contract" in times of economic reform.

23. Data for 2016 (Mesa-Lago 2018). 
24. Orig: La masa poblacional cubana es tratada de manera homogénea. Lo cual es un error de magnitud incalculable [. . . el el "color negro," se ha comportado, funcionado siempre como una variable de diferenciación social. Variable, que casi nunca ha sido tomada en consideración por nuestro aparato estadístico nacional.

\section{REFERENCES}

Abreu, Alberto. 2014. Apuntes para una cartografía en torno al debate del término Afrocubano/a. Afromodernidades (blog), April 17. https://afromodernidades.wordpress.com/ 2014/04/17/afromodernidades-59. Accessed December 5, 2018.

Bastian, Hope. 2018. Everyday Adjustments in Havana: Economic Reforms, Mobility, and Emerging Inequalities. Lanham: Lexington Books.

Blue, Sarah. 2007. The Erosion of Racial Equality in the Context of Cuba's Dual Economy. Latin American Politics and Society 49, 3: 35-68.

Brundenius, Claes, and Ricardo Torres Pérez, eds. 2013. No More Free Lunch: Reflections on the Cuban Economic Reform Process and Challenges for Transformation. New York/Heidelberg: Springer.

Carranza Valdés, Julio, Luis Gutiérrez Urdaneta, and Pedro Monreal González. 1996. Cuba, Restructuring the Economy: A Contribution to the Debate. London: Institute of Latin American Studies, University of London.

Castro, Fidel. 1993. Discurso en la clausura del 40 aniversario del asalto al Cuartel Moncada. Granma, July 28: 3-7.

Castro, Raúl. 2018. La Revolución es la obra más hermosa que hemos hecho. Discurso del General de Ejército Raúl Castro Ruz, Primer Secretario del Comité Central del Partido Comunista de Cuba, en la clausura de la Sesión Constitutiva de la IX Legislatura de la Asamblea Nacional del Poder Popular, en el Palacio de Convenciones, el 19 de abril de 2018, “Año 60 de la Revolución.” CubaDebate, April 19. http://www.cubadebate.cu/ opinion/2018/04/20/discurso-de-raul-castro-ruz/. Accessed August 30, 2019.

Cervantes-Rodríguez, Margarita. 2010. International Migration in Cuba: Accumulation, Imperial Designs, and Transnational Social Fields. University Park: Pennsylvania State University Press.

Comisión Económica para América Latina y el Caribe (CEPAL). 1997. La economía cubana: reformas estructurales y desempeño en los noventa. Mexico City: Fondo de Cultura Económica.

Coyula, Mario, and Jill Hamberg. 2004. Understanding Slums: The Case of Havana, Cuba. Working Papers on Latin America no. 04/05-4. Cambridge: David Rockefeller Center for Latin American Studies, Harvard University. http://hwpi.harvard.edu/files/drclas/ files/slumshavana.pdf

Dagher, Jihad, Ralph Chami, Peter Montiel, and Yasser Abdih. 2008. Remittances and Institutions: Are Remittances a Curse? Working Paper WP 08/29 (February 1). Washington, DC: International Monetary Fund.

De Blas, Marta. 2018. Spanish consul in Havana. Author interview (Hoffmann). Havana, February 5.

De la Fuente, Alejandro. 1995. Race and Inequality in Cuba, 1899-1981. Journal of Contemporary History 30, 1: 131-67.

. 1998. Race, National Discourse, and Politics in Cuba: An Overview. Latin American Perspectives 25, 3: 43-69. 
1999. Myths of Racial Democracy: Cuba, 1900-1912. Latin American Research Review 34, 3 (Fall): 39-73.

2008. The New Afro-Cuban Cultural Movement and the Debate on Race in Contemporary Cuba. Special issue: Cuba: 50 Years of Revolution. Journal of Latin American Studies 40, 4: 697-720.

- 2011. Race and Income Inequality in Contemporary Cuba. NACLA Report on the Americas 44, 4: 30-33.

Díaz-Briquets, Sergio. 2008. Remittances to Cuba: An Update. In Cuba in Transition, vol. 18, ed. Association for the Study of the Cuban Economy (ASCE). Coral Gables: ASCE. 154-59.

Díaz-Canel, Miguel. 2019. Intervención de Miguel Díaz-Canel Bermúdez, Presidente de los Consejos de Estado y de Ministros, durante la conclusión de la visita gubernamental a Pinar del Río. Granma, June 30. http://www.granma.cu/discursos-de-diaz-canel/201906-30/intervencion-de-miguel-diaz-canel-bermudez-presidente-de-los-consejos-deestado-y-de-ministros-durante-la-conclusion-de-la-visita-gubernamental-a-pinar-delrio-30-06-2019-09-06-18. Accessed August 31, 2019.

Domínguez, Jorge, Omar Everleny, Mayra Espina Prieto, and Lorena Barberia, eds. 2012. Cuban Economic and Social Development: Policy Reforms and Challenges in the 21st Century. Cambridge: Harvard University Press.

Eckstein, Susan. 2004. Dollarization and Its Discontents: Remittances and the Remaking of Cuba in the Post-Soviet Era. Comparative Politics 36, 3: 313-30.

Espina Prieto, Mayra. 2010. Desarrollo, desigualdad y politicas sociales: acercamientos desde una perspectiva compleja. Havana: Publicaciones Acuario, Centro Félix Varela.

Espina Prieto, Mayra, and Viviana Togores. 2012. Structural Change and Routes of Social Mobility in Today's Cuba: Patterns, Profiles, and Subjectivities. In Domínguez et al. 2012. 261-89.

Fernández-Robaina, Tomás. 1990. El negro en Cuba 1902-1958: apuntes para la historia de la lucha contra la discriminación racial. Havana: Editorial de Ciencias Sociales.

Frank, Marc. 2008. Cuba Grapples with Growing Inequality. Reuters, April 10. https://www.reuters.com/article/us-cuba-reform-inequality/cuba-grapples-with-growing-inequality-idUSN1033501920080410. Accessed December 5, 2018.

Gamez Torres, Nora. 2018. Más de 40,000 cubanos que viven en el extranjero han solicitado repatriarse a la isla. El Nuevo Herald, October 22. https://www.elnuevoherald.com/noticias/mundo/america-latina/cuba-es/article220432970.html. Accessed December 5, 2018.

Gobierno de España. 2007. Ley de Memoria Histórica 52/2007, de 26 de diciembre. Boletín Oficial del Estado, December 27. https://www.boe.es/buscar/act.php?id=BOE-A-200722296. Accessed December 5, 2018.

Golías Pérez, Montserrat. 2016. Los herederos de la ciudadanía. Los nuevos españoles a través de la ley de la memoria histórica en Cuba y Argentina. Barcelona: Icaria.

Hansing, Katrin. 2008. South-South Migration and Transnational Ties Between Cuba and Mozambique. In Transnational Ties: Cities, Migrations, and Identities, ed. Michael P. Smith and John Eade. New Brunswick: Transaction. 77-90.

- 2017. Race and Inequality in the New Cuba: Reasons, Dynamics, and Manifestations. Social Research: An International Quarterly 84, 2: 331-49.

Hansing, Katrin, and Manuel Orozco. 2011. Remittance Recipients and the Present and Future of Micro-Entrepreneurship Activities in Cuba. In Cuba in Transition, vol. 21, ed. Association for the Study of the Cuban Economy (ASCE). Coral Gables: ASCE. 302-8. 
2014. The Role and Impact of Remittances on Small Business Development During Cuba's Current Economic Reforms. DesiguALdades Working Paper 69. Berlin: Freie Universität.

Hansing, Katrin, and Sarah Mahler. 2003. God Knows No Borders: Transnational Religious Ties Linking Miami and Cuba. In Religion, Culture, and Society: The Case of Cuba, ed. Margaret E. Crahan. Washington, DC: Woodrow Wilson Center. 123-30.

- 2005. Myths and Mysticism: How Bringing a Transnational Lens to the Examination of Cuba and the Cuban Diaspora Exposes and Ruptures the Fallacy of Isolation. In Cuba Transnational, ed. Damián Fernández. Gainesville: University of Florida Press. $57-75$.

Hansing, Katrin, and Uwe Optenhögel. 2015. Las desigualdades se tornan visibles: consecuencias de la economía de escasez y reformas. Nueva Sociedad 255: 4-18.

Helg, Aline. 1995. Our Rightful Share: The Afro-Cuban Struggle for Equality, 1886-1912. Chapel Hill: University of North Carolina Press.

Hoffmann, Bert. 2004. The Politics of the Internet in Third World Development: Challenges in Contrasting Regimes with Case Studies of Costa Rica and Cuba. New York: Routledge.

- 2005. Emigration and Regime Stability: Explaining the Persistence of Cuban Socialism. Journal of Communist Studies and Transition Politics 21, 4: 436-61.

- 2016. Bureaucratic Socialism in Reform Mode: The Changing Politics of Cuba's Post-Fidel Era. Third World Quarterly 37, 9: 1730-44.

Kapur, Devesh. 2004. Remittances: The New Development Mantra? UNCTAD G-24 Discussion Paper Series. Geneva: United Nations Conference on Trade and Development.

McGarrity, Gayle L. 1992. Race, Culture, and Social Change in Contemporary Cuba. In Cuba in Transition: Crisis and Transformation, ed. Sandor Halebsky and John M. Kirk. Boulder: Westview Press. 193-205.

McGarrity, Gayle, and Osvaldo Cárdenas. 1995. Cuba. In No Longer Invisible: Afro-Latin Americans Today, ed. Pedro Pérez-Sarduy and Jean Stubbs. London: Minority Rights Publications.

Mesa Carbonell, Norberto. 2019. Carta abierta de la Cofradía de la Negritud al Presidente de los Consejos de Estrado y de Ministros. Inter Press Service en Cuba. August 15. https://www.ipscuba.net/archivo/carta-abierta-de-la-cofradia-de-la-negritud-al-presidente-de-los-consejos-de-estrado-y-de-ministros. Accessed August 30, 2019.

Mesa-Lago, Carmelo. 2005. Social and Economic Problems in Cuba During the Crisis and Subsequent Recovery. CEPAL Review 86: 177-99.

- 2018. Una apostilla sobre salarios, pensiones y asistencia social en Cuba. El Estado como tal (blog), March 10. https://elestadocomotal.com/2018/03/10/carmelo-mesalago-una-apostilla-sobre-salarios-pensiones-y-asistencia-social-en-cuba/. Accessed December 5, 2018.

Mesa-Lago, Carmelo, and Jorge F. Pérez-López. 2005. Cuba's Aborted Reform: Socioeconomic Effects, International Comparisons, and Transition Policies. Gainesville: University Press of Florida.

Ministerio de Relaciones Exteriores (MINREX). 2018. Informe nacional de la República de Cuba al examen periódico universal del Consejo de Derechos Humanos. Havana: MINREX. http://www.minrex.gob.cu/sites/default/files/imagenes/bloques/informedigitalepu.pdf. Accessed December 5, 2018.

Monreal, Pedro. 2017. Desigualdad global: ¿¿dónde se ubica Cuba? El Estado como tal (blog), April 29. https://elestadocomotal.com/2017/04/29/desigualdad-global-como-se-ubicacuba/. Accessed December 5, 2018. 
Moore, Carlos. 1988. Castro, The Blacks, and Africa. Los Angeles: Center for Afro-American Studies, University of California.

Morales, Emilio. 2019. Remittances, An Investment Route for Cubans? Havana Consulting Group, September 27. http://www.thehavanaconsultinggroup.com/en-Us/Articles/Article/69. Accessed January 3, 2020.

Morales Domínguez, Esteban. 2013. Race in Cuba: Essays on the Revolution and Racial Inequality. Trans. Gary Prevost and August Nimtz. New York: Monthly Review Press. . 2018. El tema racial en Cuba y el informe a Naciones Unidas del 2018. Un balance crítico. Esteban Morales Domínguez (blog), August 14. http://estebanmoralesdominguez. blogspot.com/2018/08/el-tema-racial-en-cuba-y-el-informe.html. Accessed December 5, 2018.

Nova González, Armando. 2019. Remesas a Cuba. Mito o realidad, tras la ruta del dinero. Inter Press Service en Cuba, July 20. https://www.ipscuba.net/economia/remesas-acuba-mito-o-realidad-tras-la-ruta-del-dinero. Accessed August 31, 20 s19.

Oficina Nacional de Estadísticas (ONE). 2016. El color de la piel según el censo de población y viviendas 2012. Havana: ONE.

2017. Panorama territorial, Cuba 2016. Havana: ONE.

2018. Salario medio en cifras, Cuba 2017. Havana: ONE.

Orozco, Manuel. 2013. Migrant Remittances and Development in the Global Economy. Boulder: Lynne Rienner.

Ortiz, Fernando. 1940. Cuban Counterpoint. Havana: Jesús Montero.

Partido Comunista de Cuba (PCC). 2011. Lineamientos de la política económica y social del Partido y la Revolución. Havana: PCC.

Pedraza, Silvia. 2007. Political Disaffection in Cuba's Revolution and Exodus. Cambridge: Cambridge University Press.

Pérez Sarduy, Pedro, and Jean Stubbs. 2000. Afro-Cuban Voices: On Race and Identity in Contemporary Cuba. Gainesville: University Press of Florida.

Periodismo de Barrio. 2018. Internet en Cuba (special issue). May 28. https://www.periodismodebarrio.org/internetencuba/2018/04/13/la-ruta-de-internet-en-cuba. Accessed December 5, 2018.

Poirine, Bernard. 1997. A Theory of Remittances as an Implicit Family Loan Arrangement. World Development 25, 4: 589-611.

Portes, Alejandro. 2007. The Cuban-American Political Machine: Reflections on its Origins and Perpetuation. In Debating Cuban Exceptionalism, ed. Bert Hoffmann and Laurence Whitehead. London: Palgrave. 123-37.

Portes, Alejandro, and Alex Stepick. 1993. City on the Edge: The Transformation of Miami. Berkeley: University of California Press.

Ratha, Dilip. 2005. Remittances: A Lifeline for Development. Finance and Development 42, 4: 42-45.

Ravsberg, Fernando. 2018. Los millones que vuelan con los cubanos. Cartas desde Cuba (blog), January 18. http://cartasdesdecuba.com/los-millones-que-vuelan-con-loscubanos. Accessed December 5, 2018.

Reigosa González, Nuria. 2018. Ministra consejera, Spanish embassy in Havana. Author interview (Hoffmann). Havana, February 2.

República de Cuba. 1992. Constitución de la República de Cuba [including the Constitutional Reform of 1992]. http://www.cuba.cu/gobierno/consti.htm. Accessed December 5, 2018. 
2019. Constitución de la República de Cuba [including the Constitutional Reform of 2019]. media.cubadebate.cu/wp-content/uploads/2019/04/Constitución-de-la-República-de-Cuba.pdf. Accessed December 5, 2018.

Ritter, Archibald. 1995. The Dual Currency Bifurcation of Cuba's Economy in the 1990s: Causes, Consequences, and Cures. CEPAL Review 57: 113-32.

- 1998. Entrepreneurship, Microenterprise, and Public Policy in Cuba: Promotion, Containment, or Asphyxiation? Journal of Interamerican Studies and World Affairs 40, 2: 63-94.

Ritter, Archibald R. M., and Nicholas Rowe. 2002. Cuba: From "Dollarization" to "Euroization" or "Peso Reconsolidation"? Latin American Politics and Society 44, 2: 99-123.

Rubiera Castillo, Daisy, and Inés María Martiatu Terry. 2011. Afrocubanas: historia, pensamiento y prácticas culturales. Havana: Editorial de Ciencias Sociales.

Shachar, Ayelet. 2017. Citizenship for Sale? In The Oxford Handbook of Citizenship, ed. Shachar, Rainer Bauböck, Irene Bloemraad, and Maarten Vink. Oxford: Oxford University Press. 794-816.

Torres, Ricardo. 2018. En Cuba hay que hablar seria y profundamente sobre desigualdad. Temas (Catalejo), September 4. http://temas.cult.cu/catalejo/ricardo-torres-en-cubahay-que-hablar-seria-y-profundamente-sobre-desigualdad. Accessed December 5, 2018.

Vidal Alejandro, Pavel, and Omar Everleny Pérez Villanueva. 2013. La reforma monetaria en Cuba hasta el 2016: entre gradualidad y "big bang." Paper prepared for workshops at the Brookings Institution and the University of Havana.

U.S. Census Bureau. 2011. The Hispanic Population: 2010. https://www.census.gov/prod/ cen2010/briefs/c2010br-04.pdf. Accessed December 5, 2018.

West-Durán, Alan. 2018. The Living Lie and the Living Eye: Cuba’s Reforms and the Racial Contract. In Paths for Cuba: Reforming Communism in Comparative Prospective, ed. Scott Morgenstern, Jorge Pérez-López, and Jerome Blanche. Pittsburgh: University of Pittsburgh Press. 299-320.

Zurbano, Roberto. 2013. For Blacks in Cuba, the Revolution Hasn't Begun. New York Times, March 23. https://www.nytimes.com/2013/03/24/opinion/sunday/for-blacksin-cuba-the-revolution-hasnt-begun.html. Accessed August 30, 2019. 